\title{
Evaluation of Serum Zinc and Copper Levels in Superficial Fungal Infections
}

\section{Yüzeyel Mantar Enfeksiyonlarında Serum Çinko ve Bakır Düzeylerinin Değerlendirilmesi}

\author{
담a Tuncez Akyurek', Fikret Akyurek² \\ 'Selcuk University School of Medicine Department of Dermatology, Konya, Turkey \\ ${ }^{2}$ Selcuk University School of Medicine Department of Biochemistry, Konya, Turkey
}

\begin{abstract}
Objective: Superficial fungal infections are one of the common skin diseases. Zinc and copper are essential elements for humans, and concentrations of these trace elements may vary in various inflammatory conditions. Our aim in this study is to measure serum zinc and copper levels in patients with superficial fungal infection and to evaluate its relationship with clinical types of the disease.

Material and Method: This study included 81 patients diagnosed with superficial fungal infection (tinea capitis, faciei, pedis, unguim, corporis, and versicolor) who applied to the Department of Skin and Venereal Diseases, Faculty of Medicine, Selcuk University. Serum zinc and copper levels were measured in all patients.

Results: The mean age of the patients was $36.68 \pm 17.12$, and 54 (66.6\%) of patients were male and $27(33.3 \%)$ were female. There were tinea versicolor in $32(39.5 \%)$ of the patients and other dermatophytosis infections (tinea capitis, faciei, pedis, unguium and corporis) in $49(60.5 \%)$ of the patients. The mean serum zinc levels of the patients were determined close to the lower limit of the normal reference range with $11.41 \pm 2.07 \mu \mathrm{mol} / \mathrm{L}$, but zinc and copper levels were within the normal reference range (normal reference values of zinc and copper; 11-19.5 $\mu \mathrm{mol} / \mathrm{L}, 80-155 \mu \mathrm{g} / \mathrm{dL}$, respectively). There was no statistically significant difference in zinc and copper levels between patients with tinea versicolor and patients with other dermatophyte infections ( $p=0.348, p=0.173$, respectively). In addition, there was a negative correlation between serum zinc levels and age, serum copper levels showed a statistically significant negative relationship with male sex and smoking $(r=-0.359, p=0.001 ; r=-0.343, p=0.002, r=-0.283$, $\mathrm{p}=0.033$, respectively).

Discussion: In our study, the majority of patients with superficial fungal infections were men. It was determined that the frequency of dermatophyte infections increased as the mean age of the patients increased. Although serum zinc and copper levels measured in patients were within the normal reference range, especially zinc levels were close to the lower limit of reference values. In addition, it was observed that various factors such as age, gender and smoking affect zinc and copper levels. As a result of these data, we think that irregularities in serum zinc and copper levels may predispose to the development of fungal infections.
\end{abstract}

Keywords: Copper, dermatophytosis, superficial fungal infections, trace elements, zinc

\section{Öz}

Amaç: Yüzeyel mantar hastalıkları sık karşılaşılan deri hastalıklarından biridir. Çinko ve bakır insanlar için esansiyel elementlerdir ve çeşitli inflamatuvar durumlarda bu eser elementlerin konsantrasyonları değişebilir. Bu çalışmada amacımız yüzeyel mantar enfeksiyonu olan hastalarda serum çinko ve bakır düzeyinin ölçmek ve bunun hastalığın klinik tipleri ile ilişkisini değerlendirmektir.

Gereç ve Yöntem: Selçuk Üniversitesi Tıp Fakültesi Deri ve Zührevi Hastalıklar bölümüne başvuran yüzeyel mantar enfeksiyonu tanısı alan (tinea capitis, fascie, pedis, unguim, corporis ve versicolor) 81 hasta dahil edildi. Tüm hastalarda serum çinko ve bakır düzeyleri ölçüldü.

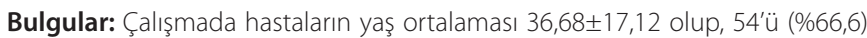
erkek ve 27 'si $(\% 33,3)$ kadındı. Hastaların 32'sinde $(\% 39,5)$ tinea versikolor, $49^{\prime} u n d a(\% 60,5)$ diğer dermatofitoz enfeksiyonları (tinea capitis, fascie, pedis, unguim ve corporis) mevcuttu. Hastaların ortalama serum çinko düzeyleri $11,41 \pm 2,07 \mu \mathrm{mol} / \mathrm{L}$ ile normal referans aralığının alt sınıına yakın saptandı ancak çinko ve bakır düzeyleri normal referans aralığında (çinko ve bakırın normal referans değerleri; sırasıyla 11-19,5 $\mu \mathrm{mol} / \mathrm{L}, 80-155 \mu \mathrm{g} / \mathrm{dL}$ ) idi. Tinea versikoloru olan ve diğer dermatofit enfeksiyonu olan hastalar arasında çinko ve bakır düzeyi açııından istatistiksel olarak anlamlı bir farklılık izlenmedi (sırasıyla $p=0,348, p=0,173$ ). Ayrıca serum çinko düzeyleri ile yaş arasında negatif korelasyon, serum bakır düzeyleri erkek cinsiyette ve sigara kullanımı ile istatistiksel olarak anlamlı negatif ilişki saptandı (sırasıyla $r=-0,359, p=0,001$; $r=-0,343, p=0,002 ; r=-0,238, p=0,033$ ).

Tartışma: Çalışmamızda yüzeyel mantar enfeksiyonu olan hastaların çoğunluğunu erkekler oluşturmaktaydı. Hastaların yaş ortalaması arttıkça dermatofit enfeksiyonlarının görülme sıklığında artış olduğu tesbit edildi. Her ne kadar hastalarda ölçülen serum çinko ve bakır düzeyleri normal referans aralığında olsa da özellikle çinko düzeyleri referans değerlerinin alt sınııına yakındı. Ayrıca yaş, cinsiyet ve sigara gibi çeşitli faktörlerin çinko ve bakır düzeylerini etkilediği gözlendi. Bu veriler sonucunda serum çinko ve bakır düzeylerindeki düzensizliklerin mantar enfeksiyonlarına yatkınık oluşturabileceğini düşünmekteyiz.

Anahtar Kelimeler: Bakır, çinko, dermatofitozis, eser element, yüzeyel mantar enfeksiyonları

Corresponding (illetişim): Fatma Tuncez Akyurek, Selcuk University School of Medicine Department of Dermatology, Konya, Turkey E-mail (E-posta): dermafatma@yahoo.com.tr

Received (Geliş Tarihi): 14.09.2020 Accepted (Kabul Tarihi): 24.09.2020 


\section{INTRODUCTION}

Superficial fungal infections are common worldwide. It can affect skin, hair and nails in humans and animals. The most common form of superficial fungal infections of the skin is dermatophyte infection caused by trichophyton, microsporum and epidermophyton. Less frequently yeasts (eg malassezia furfur, candida) may be cause. ${ }^{[1,2]}$ Diabetes mellitus (DM), immunodeficiency or the use of immunosuppressive drugs, humidity and contact to the infected materials increase the susceptibility to this disease. Although some dermatophyte infections are widespread all over the world, they are observed frequently or infrequently, depending on the climate, life and economic conditions of the region. ${ }^{[3,4]}$ Trace elements such as copper $(\mathrm{Cu})$, zinc $(\mathrm{Zn})$ are components and/or cofactors of many proteins and enzymes required for normal body functions. Various inflammatory and immunological conditions may also change the concentrations of $\mathrm{Zn}$ and Cu elements. ${ }^{[5,6]}$

Although there have been previous studies showing the relationship between dermatophyte infections and trace elements in humans and animals, studies on this subject are limited. ${ }^{[7,8]}$ In line with this information, it is aimed to evaluate the level of $\mathrm{Zn}$ and $\mathrm{Cu}$ in patients who applied to the dermatology clinic and diagnosed with superficial fungal infection.

\section{MATERIAL AND METHOD}

This study included superficial fungal infection patients (tinea capitis, faciei, pedis, unguim, corporis, and versicolor) who applied to the Department of Skin and Venereal Diseases, Faculty of Medicine, Selcuk University. The diagnosis of superficial fungal infections was made with clinical appearance, auxiliary diagnostic methods (direct microscopy and wood lamp), and fungal culture where necessary. Age, gender, disease duration, clinical type of superficial fungal infection were recorded in all patients. Patients with active superficial fungal infection, who had not received systemic treatment for the past three months and topical antifungal treatment for the past 1 month were included in the study. Patients who received $\mathrm{Zn}, \mathrm{Cu}$ and vitamin supplements, had known immunodeficiency, received immunosuppressive therapy, who had malignancy, and were in pregnancy and lactation period were not included in the study. Plasma samples were taken from the brachial vein via vacutainer to the BDR trace element tubes containing clot activator. After the samples were centrifuged at $4000 \mathrm{~g}$ for 10 minutes, their plasma was separated. $\mathrm{Cu}$ and $\mathrm{Zn}$ elements from the separated plasma samples were studied in VARIAN (AA240FS, Australia) flammable atomic absorption spectrometry (AAS). During the study, plasma samples were analyzed by diluting $1 / 5$ with $0.1 \% \mathrm{HNO}_{3}$. While analyzing with AAS, gas flow was provided with acetylene gas. The value of analytes was calculated using the instrument's own software, using five-point calibrators. The reference range values for $\mathrm{Cu}$ are

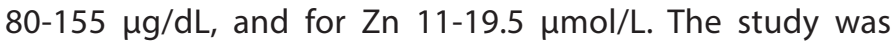
approved by the Local Ethics Committee of Selcuk University (approval number: 2019/62).

\section{Statistical analysis}

The data were evaluated with IBM SPPS statistics 21 package program. The examined variables are indicated with mean \pm standard deviation values. After looking at whether the parameters were normally distributed or not, the evaluation was made. In the analysis of the data, Student's $\mathrm{T}$ test was used for group comparisons, and in the absence of a normal distribution, Mann Whitney-U test was used. The relationship between the two variables was evaluated using the Pearson correlation test in parametric tests and the Spearman correlation test in non-parametric tests. The effect of gender on the incidence of diseases was evaluated by $x 2$ test. For the significance level of the tests, $p<0.05$ and $p<0.01$ value were accepted.

\section{RESULT}

Eighty-one patients diagnosed with superficial fungal infection were included in the study. The mean age of the patients was $36.68 \pm 17.12$, and $54(66.6 \%)$ of patients were male and 27 (33.3\%) were female. There were tinea versicolor in $32(39.5 \%)$ of the patients and other dermatophytosis infections (tinea capitis, faciei, pedis, unguium and corporis) in $49(60.5 \%)$ of the patients. The mean age was $30.59 \pm 10.98$ in patients with tinea versicolor, whereas it was $40.65 \pm 19.23$ in patients with other dermatophyte infections. The average age of patients with dermatophyte infection was higher than those with tinea versicolor $(p=0.009)$. When the average age of both groups was compared by gender, the mean age of males with dermatophyte infection was found to be significantly higher than that of males with tinea versicolor, whereas there was no significant difference in females ( $p=0.003, p=0.966$, respectively). The mean body mass index (BMI) of the patients was $25.78 \pm 5.41$. There was no statistically significant difference between the groups in terms of gender and BMI ( $p=0.305, p=0.09$, respectively). The most obvious symptom of the patients was itching. While the average $\mathrm{Cu}$ levels of all patients were $108.88 \pm 21.02 \mu \mathrm{g} / \mathrm{dL}$, the $\mathrm{Zn}$ levels were $11.41 \pm 2.07 \mu \mathrm{mol} / \mathrm{L}$. Cu levels were 104,92 $\pm 21,11 \mu \mathrm{g} /$ $\mathrm{dL}$ in patients with tinea versicolor, whereas $111,46 \pm 20,77$ $\mu \mathrm{g} / \mathrm{dL}$ in other dermotophyte infections. Zn levels were $11.68 \pm 2.03 \mu \mathrm{mol} / \mathrm{L}$ in patients with tinea versicolor, whereas $11.24 \pm 2.10 \mu \mathrm{mol} / \mathrm{L}$ in other dermotophyte infections. There was no statistically significant difference between the groups in terms of $Z n$ and Cu levels ( $p=0.348, p=0.173$, respectively) (Table 1). 
Table 1. Comparison of tinea versicolor and other dermatophyte infections groups

\begin{tabular}{lccccccc} 
& \multicolumn{3}{c}{ Tinea versicolor } & \multicolumn{3}{c}{$\begin{array}{c}\text { Other dermatophyte } \\
\text { infections }\end{array}$} & \multirow{2}{*}{$\mathbf{p}$} \\
\cline { 2 - 6 } & $\mathbf{n}$ & Mean & SD & $\mathbf{n}$ & Mean & SD & \\
\hline $\mathrm{Age}$ & 32 & 30.59 & 10.98 & 49 & 40.65 & 19.23 & $0.009^{* *}$ \\
$\mathrm{BMI}$ & 32 & 24.52 & 4.85 & 49 & 26.61 & 5.64 & 0.090 \\
$\mathrm{Cu}$ & 32 & 104.92 & 21.11 & 49 & 111.46 & 20.77 & 0.173 \\
$\mathrm{Zn}$ & 32 & 11.68 & 2.03 & 49 & 11.24 & 2.10 & 0.348 \\
$\mathrm{Cu} / \mathrm{Zn}$ & 32 & 9.30 & 2.58 & 49 & 10.40 & 3.41 & 0.123 \\
\hline${ }^{* *} \mathrm{p}<0.01$ & & & & & & & \\
\hline
\end{tabular}

Age, BMI, serum $\mathrm{Zn}$ and $\mathrm{Cu}$ levels and $\mathrm{Cu} / \mathrm{Zn}$ ratios between groups according to gender are shown in Table 2 . No statistically significant difference was observed between male and female patients with superficial fungal infections in terms of serum $\mathrm{Zn}$ levels $(p=0.4)$. Cu levels and $\mathrm{Cu} / \mathrm{Zn}$ ratio in males were significantly lower than females $(p=0.002,0.009$, respectively).

Table 2. Age, BMl, serum $\mathrm{Zn}$ and $\mathrm{Cu}$ levels and $\mathrm{Cu} / \mathrm{Zn}$ ratios between groups according to gender

\begin{tabular}{lccccccc} 
& \multicolumn{4}{c}{ Male } & \multicolumn{5}{c}{ Female } & \\
\cline { 2 - 6 } & $\mathbf{n}$ & Mean & SD & $\mathbf{n}$ & Mean & SD & p \\
\hline Age & 54 & 38.70 & 17.91 & 27 & 32.63 & 14.91 & 0.133 \\
$\mathrm{BMI}$ & 54 & 26.13 & 5.01 & 27 & 25.08 & 6.17 & 0.412 \\
$\mathrm{Cu}$ & 54 & 103.81 & 19.20 & 27 & 119.02 & 21.16 & $0.002^{* *}$ \\
$\mathrm{Zn}$ & 54 & 11.55 & 2.07 & 27 & 11.13 & 2.08 & 0.400 \\
$\mathrm{Cu} / \mathrm{Zn}$ & 54 & 9.32 & 2.60 & 27 & 11.23 & 3.74 & $0.009^{* *}$ \\
\hline${ }^{* *} \mathrm{p}<0.01$ & & & & & & & \\
\hline
\end{tabular}

In addition, $\mathrm{Cu}$ levels were lower in smokers than nonsmokers and this was statistically significant $(p=0.033)$. There was a negative correlation between the patients' age and $Z n$ levels and was statistically significant $(r=-0.359, p=0.001)$. In addition, there was a statistically significant negative correlation with serum $\mathrm{Cu}$ levels and male sex and smoking $(r=-0.343, p=0.002 ; r=-0.283, p=0.033$, respectively). There was a negative correlation between disease duration and $\mathrm{Cu} / \mathrm{Zn}$, but there was no statistically significant difference (Table $\mathbf{3}$ ).

\section{DISCUSSION}

Dermatophytoses are infections caused by dermatophytes and are named according to the affected area (tinea pedis, fascie, manum, capitis, corporis and ungium). Pityriasis versicolor is a common, benign, recurrent, chronic skin infection caused by malassezia yeasts. It is generally asymptomatic and not contagious. In dermatological examination, small, round or oval, thin scaly, hypo/hyperpigmented (yellow-brown) lesions are seen ${ }^{[3,9]}$ Superficial fungal infections common in the world affect $20 \%$ of the population. It is more common in men than in women. $90 \%$ of adult men have had a superficial fungal infection at least once in their lifetime. ${ }^{[10]}$ In our study, the majority of patients were male (male $66.6 \%$, female $33.3 \%$ ), similar to the literature.

The severity and prevalence of the fungal infection depends on the pathogen and the host's immune system. In addition, various factors such as age, geographic region, climatic conditions and socioeconomic status also affect the frequency of dermatophytosis..$^{[4,1]}$ In our study, the incidence of dermatophyte infections increased as the age increased. Compared to tinea versicolor, dermatophyte infections were seen at a later age in males, but there was no significant difference in females.

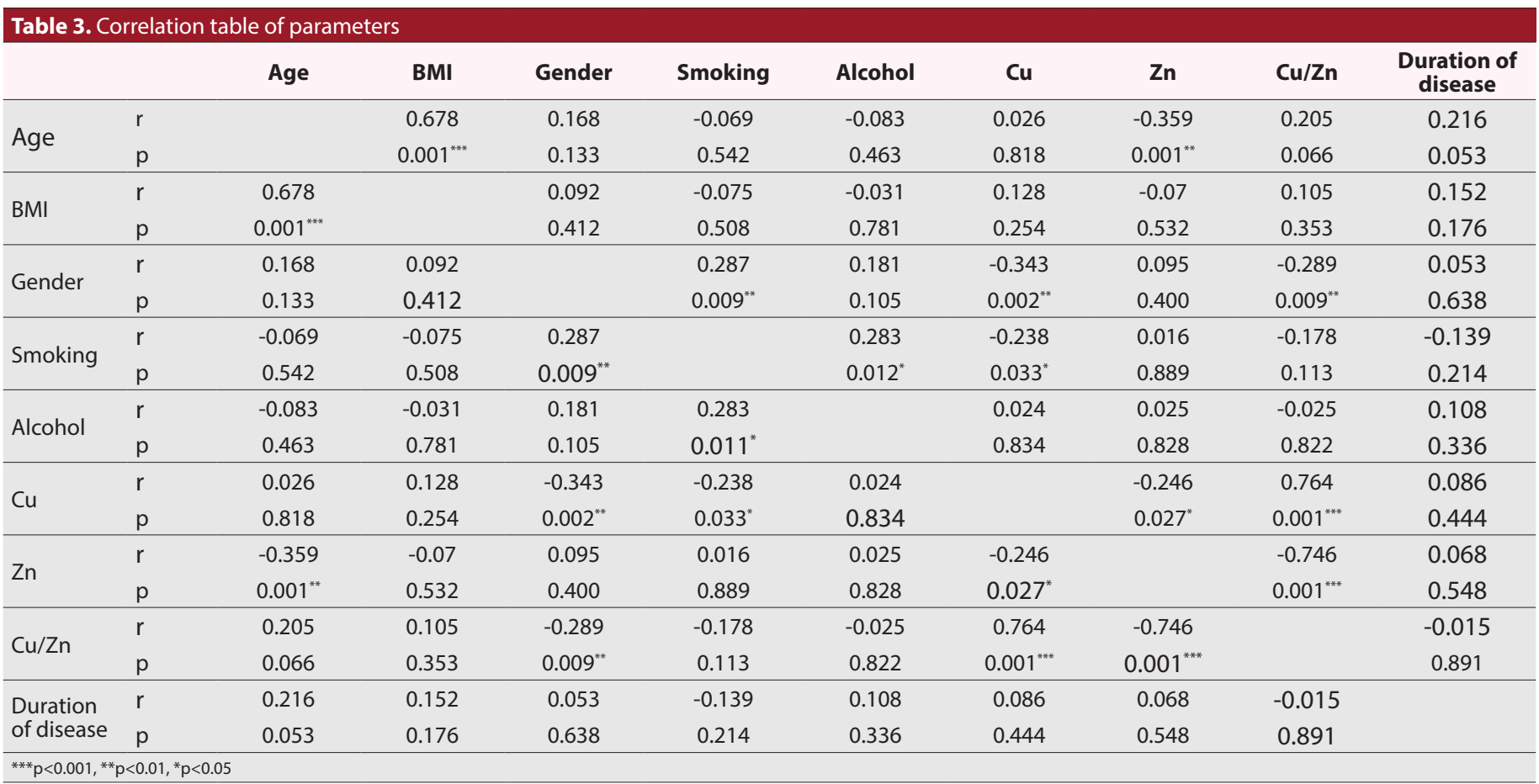


$\mathrm{Zn}$ is an essential element for the organism. Besides playing role in differentiation of epidermal keratinocytes, $\mathrm{Zn}$ has anti-inflammatory properties and also plays a role in wound healing. It has multiple effects on the immune system such as the proliferation and activation of $\mathrm{T}$ and $\mathrm{B}$ lymphocytes, the regulation of Th1 and Th2 immune responses by cytokine production, and the phagocytic and lytic effects of natural killer cells, neutrophils and macrophages. ${ }^{[12,13]}$ The tendency for viral, bacterial, parasitic and fungal infections increases with $\mathrm{Zn}$ deficiency. In addition, $\mathrm{Zn}$ is an antioxidant and provides membrane stabilization. ${ }^{[14,15]}$ Approximately $17 \%$ of the world's population has Zn deficiency. Especially preterm babies, pregnant women and elderly individuals are risky papulations for acquired Zn deficiency. ${ }^{[12]} \mathrm{Zn}$ deficiency has been reported in many inflammatory and autoimmune dermatological diseases such as alopecies, psoriasis, atopic dermatitis, Behçet's disease and bullous diseases. ${ }^{[16]}$ In our study, there was a significant decrease in Zn levels with increasing age. Also, the mean age of those with dermatophyte infection was higher than those of tinea versicolor. These data suggested that a decrease in the level of $Z n$, which develops in the older ages, may predispose to dermatophyte infections. Cu plays a role as a cofactor in the structure of protein and DNA synthesis, antioxidant system, and many enzymes involved in the immune system. Therefore, even in minimal deficiencies, there may be changes in the immune response. ${ }^{[17]}$ The balance in $\mathrm{Zn} / \mathrm{Cu}$ ratios is necessary for normal biochemical and physiological changes and protects from various chronic diseases. Various factors such as aging, smoking, alcohol, stress and socioeconomic factors can cause changes in $\mathrm{Zn}$ and $\mathrm{Cu}$ concentrations. In a study investigating the relationship of $\mathrm{Zn}$ and $\mathrm{Cu}$ levels to various factors such as age, gender, smoking and socioeconomic status in healthy individuals living in Jinan city, serum $\mathrm{Zn}$ and $\mathrm{Zn} / \mathrm{Cu}$ levels were higher and $\mathrm{Cu}$ levels were lower in men. In addition, while serum Cu levels were low in smokers, no significant difference was found in $\mathrm{Zn}$ and $\mathrm{Zn} /$ Cu levels. ${ }^{[18]}$ In our study, similar to this study, Cu levels were lower in male patients and smokers. While $\mathrm{Cu} / \mathrm{Zn}$ ratios were lower in males, there was no significant difference in $\mathrm{Zn}$ levels. In smokers, we did not find any difference in terms of $Z n$ values and $\mathrm{Cu} / \mathrm{Zn}$ ratios.

Various studies have been conducted investigating the relationship of dermatophyte infections and elements. In the literature, there are studies evaluating the activity of trace elements and various antioxidant enzymes in animals with dermatophytosis. $\mathrm{Zn}$ and $\mathrm{Cu}$ levels were significantly low in dogs and cows with dermatophyte infection. The authors emphasized that the activities of antioxidant enzymes are related to the concentration of these trace elements and that these findings should be considered in the therapeutic approaches of dermatophytosis. ${ }^{[7,19]} \mathrm{Zn}$ and $\mathrm{Cu}$ levels in humans have been studied in many diseases, but the number of studies evaluating the relationship between fungal infections and $\mathrm{Zn}$ and $\mathrm{Cu}$ is limited. Serum $\mathrm{Zn}$ levels were found lower than healthy controls in a study in which
Spacek et al evaluated serum magnesium, calcium, $\mathrm{Zn}$ and iron in patients with recurrent vulvovaginal candidiasis. They also reported that $\mathrm{Zn}$ supplementation may be beneficial in these patients. ${ }^{[20]}$ In our study, the mean serum Zn levels in those with superficial fungal infections were close to the lower limit of the reference range of $\mathrm{Zn}$. However, when the tinea versicolor and dermatophyte infections were compared, no significant difference was found in terms of $Z n$ values. We also think that low $\mathrm{Zn}$ may predispose to fungal infection. However, it may be more useful to conduct studies comparing the sufficient number of patients with subgroups of superficial fungal infections and $\mathrm{Zn}$ levels of healthy controls.

Miraloğlu et al. found that $\mathrm{Cu}$ levels were high and $\mathrm{Zn}$ and selenium levels were low in lesional areas compared to nonlesional areas in their studies evaluating local concentrations of oxidative stress and trace elements in patients with tinea pedis. They reported that high concentrations of $\mathrm{Cu}$ in the lesional area may be due to Cu released during inflammatory tissue damage. In addition, they found $\mathrm{Cu} / \mathrm{Zn}$ and $\mathrm{Cu} / \mathrm{Se}$ ratios significantly higher in the lesional area compared to the nonlesional area. It has been reported that low $\mathrm{Zn}$ in the lesional area may be associated with increased intestinal $\mathrm{Cu}$ absorption secondary to $\mathrm{Zn}$ deficiency in patients with tinea pedis.[8] In our study, serum Zn and Cu levels were evaluated in patients with superficial fungal infection. In superficial fungal infections, in order to clearly understand the importance of the balance between $\mathrm{Zn}$ and $\mathrm{Cu}$, studies where local and systemic levels of these elements are evaluated together are needed.

\section{CONCLUSION}

Superficial dermatophyte infections are more common in men. Dermatophyte infections are seen in older ages especially in men compared to tinea versicolor. Various factors such as age and smoking may affect serum $\mathrm{Cu}$ and $\mathrm{Zn}$ levels. Irregularities in the serum levels of these elements may cause to fungal infections. We think that serum $\mathrm{Zn}$ and $\mathrm{Cu}$ levels can be evaluated in superficial fungal infections and adjusted doses of these elements can be used as a supplement to treatment when necessary. There are many studies evaluating the serum levels of trace elements and their relationship with diseases in dermatological diseases. However, the study evaluating the serum levels of trace elements such as $\mathrm{Cu}$ and $\mathrm{Zn}$ in superficial fungal infections is limited. Our study may be a guide for further studies in which Zn and Cu levels are evaluated locally and systemically, involving more patient populations covering subgroups of superficial fungal infections.

The limitations of the study are the absence of a control group and the limited number of patients.

\section{ETHICAL DECLARATIONS}

Ethics Committee Approval: The study was carried out with the permission of Local Ethics Committee of Selcuk University (approval number: 2019/62). 
Informed Consent: All patients signed the free and informed consent form.

Referee Evaluation Process: Externally peer-reviewed. Conflict of Interest Statement: The authors have no conflicts of interest to declare.

Financial Disclosure: The authors declared that this study has received no financial support.

Author Contributions: All of the authors declare that they have all participated in the design, execution, and analysis of the paper, and that they have approved the final version.

\section{REFERENCES}

1. Ameen M. Epidemiology of superficial fungal infections. Clin Dermatol 2010;28(2):197-201.

2. Silva-Rocha WP, de Azevedo MF, Chaves GM. Epidemiology and fungal species distribution of superficial mycoses in Northeast Brazil. J Mycol Med 2017;27(1):57-64.

3. Nenoff P, Krüger C, Ginter-Hanselmayer G, Tietz HJ. Mycology - an update. Part 1: Dermatomycoses: causative agents, epidemiology and pathogenesis. J Dtsch Dermatol Ges 2014;12(3):188-212.

4. Metintas S, Kiraz N, Arslantas D, et al. Frequency and risk factors of dermatophytosis in students living in rural areas in Eskişehir, Turkey. Mycopathologia 2004;157(4):379-82

5. Chan S, Gerson B, Subramaniam S. The role of copper, molybdenum, selenium, and zinc in nutrition and health. Clin Lab Med 1998;18(4):67385.

6. Ozturk P, Belge Kurutas E, Ataseven A. Copper/zinc and copper/selenium ratios, and oxidative stress as biochemical markers in recurrent aphthous stomatitis. J Trace Elem Med Biol 2013;27(4):312-6.

7. Al-Qudah KM, Gharaibeh AA, Al-Shyyab MM. Trace minerals status and antioxidant enzymes activities in calves with dermatophytosis. Biol Trace Elem Res 2010;136(1):40-7.

8. Miraloglu M, Kurutas EB, Ozturk P, Arican O. Evaluation of local trace element status and 8-Iso-prostaglandin $\mathrm{F} 2 \mathrm{a}$ concentrations in patients with Tinea pedis. Biol Proced Online 2016;18:1.

9. Zhan P, Liu W. The Changing Face of Dermatophytic Infections Worldwide. Mycopathologia 2017;182(1-2):77-86.

10. Rezabek GH, Friedman AD. Superficial fungal infections of the skin. Diagnosis and current treatment recommendations. Drugs 1992;43(5):674-82.

11. Asticcioli S, Di Silverio A, Sacco L, Fusi I, Vincenti L, Romero E. Dermatophyte infections in patients attending a tertiary care hospital in northern Italy. New Microbiol 2008;31(4):543-8.

12. Glutsch V, Hamm H, Goebeler M. Zinc and skin: an update. J Dtsch Dermatol Ges 2019;17(6):589-96.

13. Ogawa Y, Kawamura T, Shimada S. Zinc and skin biology. Arch Biochem Biophys 2016;611:113-9.

14. Gao H, Dai W, Zhao L, Min J, Wang F. The Role of Zinc and Zinc Homeostasis in Macrophage Function. J Immunol Res 2018;2018:6872621.

15. Shankar AH, Prasad AS. Zinc and immune function: the biological basis of altered resistance to infection. Am J Clin Nutr 1998;68(2 Suppl):447S-463S.

16. Ogawa Y, Kinoshita M, Shimada S, Kawamura T. Zinc and Skin Disorders. Nutrients 2018;10(2):199

17. Toyran M, Kaymak M, Vezir E, et al. Trace element levels in children with atopic dermatitis. J Investig Allergol Clin Immunol 2012;22(5):341-4.

18. Zhang HQ, Li N, Zhang Z, et al. Serum zinc, copper, and zinc/copper in healthy residents of Jinan. Biol Trace Elem Res 2009;131(1):25-32.

19. Beigh SA, Soodan JS, Singh R, Khan AM, Dar MA. Evaluation of trace elements, oxidant/antioxidant status, vitamin $C$ and $\beta$-carotene in dogs with dermatophytosis. Mycoses 2014;57(6):358-65.
20. Spacek J, Jilek P, Buchta V, Forstl M, Hronek M, Holeckova M. The serum levels of calcium, magnesium, iron and zinc in patients with recurrent vulvovaginal candidosis during attack, remission and in healthy controls. Mycoses 2005;48(6):391-5. 